\title{
The Relationship between Academic Self-Efficacy and Cognitive Flexibility: Physical Education and Sports Teacher Candidates
}

\section{La relación entre la autoeficacia académica y la flexibilidad cognitiva: candidatos a maestros de educación física y deportes}

\section{Şirin Pepe}

The Ministry of National Education, Zeki Altındağ Secondary School, Selçuklu, KonyaTurkey

ORCID ID: https://orcid.org/0000-0001-6062-8172

*Correspondence

Email: sirinpepe@ hotmail.com

\section{Cite as:}

Pepe, S. (2021). The Relationship between Academic SelfEfficacy and Cognitive Flexibility: Physical Education and Sports Teacher Candidates. Propósitos y Representaciones, 9 (SPE3), e1159. Doi: http://dx.doi.org/10.20511/pyr2021.v9nSPE3.1159 


\section{Summary}

The aim of this study is to examine the relationship between academic self-efficacy and cognitive flexibility levels of physical education and sports teacher candidates. The universe of the study consisted of 480 teacher candidates studying in the physical education and sports teaching departments of the sports sciences faculties within Selçuk, Erciyes, Süleyman Demirel and Mehmet Akif Ersoy Universities, and the sample group consisted of 192 volunteers from the specified population. Participants in the study were asked to fill in a personal information form, academic self-efficacy and cognitive flexibility scales. IBM SPSS 22.0 (Statistical Package for the Social Sciences) statistical package program was used to analyze the data. Arithmetic means and standard deviations of the scores of the volunteers from the scales were presented as $\mathrm{X} \pm \mathrm{Sd}$. Pearson Product Moment Correlation Analysis was applied to reveal the relationship of the data obtained from the scales. The value of $\mathrm{p}<0,05$ was considered significant. As a result, it was determined that the academic self-efficacy and cognitive flexibility levels of physical education and sports teacher candidates were above average. A moderate positive correlation was found between academic self-efficacy and alternatives and control subtitles of cognitive flexibility and total of cognitive flexibility. It is thought that this situation is due to the ability of physical education and sports teacher candidates to transfer their experiences in sports life to their education life.

Keywords: Physical Education and Sports, Academic Self-efficacy, Cognitive Flexibility.

\section{Resumen}

El objetivo de este estudio es examinar la relación entre la autoeficacia académica y los niveles de flexibilidad cognitiva de los candidatos a profesores de educación física y deportes. El universo del estudio consistió en 480 candidatos a maestros que estudian en los departamentos de enseñanza de educación física y deportes de las facultades de ciencias del deporte dentro de las universidades de Selçuk, Erciyes, Süleyman Demirel y Mehmet Akif Ersoy, y el grupo de muestra consistió en 192 voluntarios de la población especificada. Se pidió a los participantes del estudio que cumplimentaran un formulario de información personal, escalas de autoeficacia académica y flexibilidad cognitiva. Se utilizó el programa de paquete estadístico IBM SPSS 22.0 (Statistical Package for the Social Sciences) para analizar los datos. Las medias aritméticas y las desviaciones estándar de las puntuaciones de los voluntarios de las escalas se presentaron como $\mathrm{X} \pm \mathrm{Sd}$. Se aplicó el Análisis de Correlación Momento del Producto de Pearson para revelar la relación de los datos obtenidos de las escalas. Se consideró significativo el valor de $\mathrm{p}<0,05$. Como resultado, se determinó que los niveles de autoeficacia académica y flexibilidad cognitiva de los candidatos a maestros de educación física y deportes estaban por encima del promedio. Se encontró una correlación positiva moderada entre la autoeficacia académica y las alternativas y subtítulos de control de flexibilidad cognitiva y total de flexibilidad cognitiva. Se piensa que esta situación se debe a la capacidad de los aspirantes a profesores de educación física y deporte para trasladar sus experiencias en la vida deportiva a su vida educativa.

Palabras clave: Educación Física y Deporte, Autoeficacia académica, Flexibilidad cognitiva.

\section{Introduction}

Today, there are changes that are getting faster in all areas of life. The key role in reflecting these rapid changes to the system is education. Especially university education is a very critical stage in terms of academic success that affects individuals throughout their lives and transfers their success to the later stages of their lives (Akinci, 2020). At this stage, it is known that individuals' self-efficacy is very important for reaching predetermined goals or for solving problems they encounter in the process of achieving them.

Bandura (1997) defines the concept of self-efficacy as "personal belief in the ability of the person to plan and carry out the actions necessary in the process of achieving the determined goals", in 
other words, the individual's belief in his competencies and potential. The concept of academic self-efficacy can be defined as the perception that an individual can fulfill a certain academic task and responsibility at a certain level of success (Frozen et al, 2017). According to another definition, academic self-efficacy is related to an individual's motivation, academic choices and success (Pajares, 1996).

Individuals may face various problems both during their education and in different periods of their daily lives.They may have to decide and make a choice in the face of these problems. These types of situations are known to strengthen individuals' need to be cognitively flexible.

Individuals face two main challenges as a result of a constantly changing environment. The first of these challenges is to continue pursuing goals despite distraction; the second one is to be flexible in the change of goals and prior knowledge (in memory) in order to respond logically to environmental variables (Dreisbach, and Goschke, 2004). Deak (2003) stated that cognitive flexibility is a distinctive feature of human intelligence. In addition, he defined cognitive flexibility as the ability to adapt to unknown and unexpected situations, to create new meanings about this new situation, and to create new representations by creatively synthesizing new information and using known knowledge and habits (Deak, 2003).

In the literature review made by the researcher; studies examining the subjects of general/academic self-efficacy in different sample groups (Aydın, 2014; Caba and Pekel, 2017; Turan et al, 2016; Saracaloğlu et al, 2017; Bell and Kozlowski, 2002, Dalbudak and Musa, 2019, Y1lmaz et al, 2020) and cognitive flexibility (Erdogan, 2018; Alper and Deryakulu, 2008; Aslan, 2018; Dalkılıç 2017, Canas et al, 2003; Hamtiaux and Houssemand, 2012; Kim and Omizo, 2005; Dril, 2011) has been observed. However, any study examining these two concepts of physical education and sports teacher candidates has not been found. The aim of this study is to examine the relationship between academic self-efficacy and cognitive flexibility of physical education and sports teacher candidates.

\section{Methodology}

In the study, a method for descriptive survey (survey) and relational survey aiming to reveal the current situation was used. Descriptive scanning models are a research approach that aims to describe a past or present situation as it exists. The event, individual or object that is subject to research is tried to be defined in its own conditions and as it is. No effort is made to change or influence them in any way. On the other hand, relational survey models are research models that aim to determine the presence and/or degree of change between two or more variables (Karasar 2004).

\section{Selection of Volunteer Groups}

The universe of the study consisted of 480 teacher candidates studying in the physical education and sports teaching departments of the sports sciences faculties of Selçuk, Erciyes, Süleyman Demirel and Mehmet Akif Ersoy Universities, and the sample group consisted of 192 volunteers from the specified population.

\section{Data Collection Tools}

It was prepared by using the Google Forms platform to collect data. This method was preferred in order to maintain social distance during the pandemic process. During the data collection process, information and questionnaires about the study were communicated to the participants through social networks. The physical education and sports teacher candidates participating in the study were asked to fill in the personal information form, academic self-efficacy and cognitive flexibility scales.

\section{Personal Information Form}

Physical education teacher candidates participating in the study were asked to fill in a fivequestion personal information form covering age, gender, university they studied, overall 
academic grade point average, and weekly study time. The responses of the participants to the personal information form were presented in Table 1.

Table 1. Descriptive Statistics of Participants

\begin{tabular}{llll}
\hline & Variables & $\mathrm{n}$ & $\%$ \\
\hline \multirow{3}{*}{ Gender } & Male & 126 & 65.6 \\
& Female & 66 & 34.4 \\
& Total & 192 & 100 \\
\hline \multirow{4}{*}{ Age } & $18-20$ & 110 & 57.3 \\
& $21-23$ & 56 & 29.2 \\
& 24 and above & 26 & 13.5 \\
General Academic Grade Point & Total & 192 & 100 \\
Average & $0-1,99$ (Low) & 9 & 4.6 \\
& $2,00-2,99$ (Medium) & 94 & 49.0 \\
& $3,00-4,00$ (High) & 89 & 46.4 \\
\multirow{4}{*}{ University } & Total & 192 & 100 \\
& Süleyman Demirel & 42 & 21.9 \\
& Erciyes & 53 & 27.6 \\
& Selçuk & 56 & 29.2 \\
Weekly Study Time & Mehmet Akif Ersoy & 41 & 21.4 \\
& Total & 192 & 100 \\
\hline & $1-5$ & 120 & 62.5 \\
& $6-10$ & 50 & 26.0 \\
& 11 and above & 22 & 11.5 \\
& Total & 192 & 100 \\
\hline
\end{tabular}

When Table 1 was examined, it was seen that $65.6 \%$ of the participants are male, $34.4 \%$ of them are female; according to age variable $57.3 \%$ of them are $18-20,29.2 \%$ of them are $21-23$ and $13.5 \%$ of them are 24 years and above; according to general academic grade point average variable, $4.6 \%$ of them was low, $49 \%$ of them was medium and $46.4 \%$ of them was high; according to the university variable, $21.9 \%$ of them was Süleyman Demirel, $27.6 \%$ of them Erciyes, 29.2\% of them Selçuk and 21.4\% of them Mehmet Akif Ersoy; according to weekly study time, $62.5 \%$ of them were $1-5,26.0 \%$ of them were $6-10$ and $11.5 \%$ of them were 11 hours or more.

\section{Academic Self-Efficacy Scale:}

Academic Self-efficacy Scale, adapted from Jerusalem \& Schwarzer (1981) consists of 7 items. It was evaluated by the relevant experts in terms of the suitability for Turkish, content and assessment. In order to determine the validity and reliability of the scale, which was prepared in line with the opinions received, it was piloted by Yllmaz et al. (2007). As a result of the factor analysis, it was determined that the scale, which was adapted to Turkish, was one-dimensional, just like the original one. Cronbach Alpha internal consistency coefficient for the reliability of the scale was calculated as .79.

\section{Cognitive Flexibility Inventory:}

Cognitive Flexibility scale, developed by Dennis and Vander Wal (2010) and adapted to Turkish by Sapmaz and Doğan (2013) was used. The Cognitive Flexibility Inventory is a 5-point Likert type with 20 questions and consists of two sub-dimensions: "control" and "alternatives". While the questions numbered $1,3,5,6,8,10,12,13,14,16,18,19$ and 20 of the scale constitute the "Alternatives" dimension, the questions numbered 2, 4, 7, 9, 11, 15 and 17 constitute the "Control" dimension. Three different scores can be obtained in total in the control sub-dimension and alternatives sub-dimension of the scale. The high scores show the high cognitive flexibility. 
In the adaptation study of the scale to Turkish, the Cronbach Alpha reliability coefficients were found to be 0.90 for the whole scale; 0.84 for the "control" sub-dimension and 0.90 for the "alternatives" sub-dimension (Sapmaz and Doğan, 2013).

\section{Statistical analysis}

After checking the prerequisites for normality of variables and homogeneity of variances, Kolmogorov-Smirnov test was evaluated. Kolmogov-Smirnov test is one of the methods used to examine the normality states of the data obtained in the study, and the skewness-kurtosis distributions were given in Table 2.

Table 2. The Skewness-Kurtosis and Kolmogorov-Smirnov Test Significance Level Results of Scale Scores

\begin{tabular}{lllll}
\hline & $\mathrm{n}$ & Skewness & Kurtosis & $\mathrm{p}$ \\
\hline Academic Self-Efficacy & 192 & -.315 & -.460 & .000 \\
\hline Alternatives & 192 & .858 & .251 & .000 \\
Control & 192 & .648 & -.382 & .000 \\
Cognitive Flexibility Total & 192 & .844 & .085 & .000 \\
\hline
\end{tabular}

When the Kolmogorov-Smirnov Test results were examined in Table 2, it was observed that the deviations from normality of the scores obtained from the participants' academic self-efficacy and cognitive flexibility scales were found to be significant. On the other hand, Büyüköztürk interpreted the fact that these values are in the range of \pm 1 as there is no excessive deviations from normality (Büyüköztürk, 2007). Similarly, George and Mellery (2016) stated that the kurtosis and skewness coefficients between \pm 1 could be accepted. In the light of this information, it was accepted that the data showed a normal distribution.

IBM SPSS (Statistical Package for the Social Sciences) 22 statistical package program was used to analyze the data. The arithmetic mean and standard deviation of the scores of the participants in the academic self-efficacy and cognitive flexibility scales presented as $\mathrm{X} \pm \mathrm{Sd}$. Pearson Product Moment Correlation Analysis was applied to reveal the relationship of the data obtained from the scales. The value of $\mathrm{p}<0.05$ was considered significant.

\section{Results}

Table 3 Descriptive Statistics of Participants' Scores Obtained from Academic SelfEfficacy and Cognitive Flexibility Scales

\begin{tabular}{lllll}
\hline & $\mathrm{n}$ & Min & Max & $\mathrm{X} \pm$ SD \\
\hline Academic Self-Efficacy & 192 & 14.00 & 28.00 & $22.224 \pm 3.400$ \\
\hline Alternatives & 192 & 38.00 & 65.00 & $48.333 \pm 7.098$ \\
Control & 192 & 21.00 & 35.00 & $27.589 \pm 3.553$ \\
Cognitive Flexibility Total & 192 & 61.00 & 100.00 & $75.922 \pm 10.407$ \\
\hline
\end{tabular}

When Table 3 was examined, it was found that the academic self-efficacy levels of the physical education and sports teacher candidates were $22.224 \pm 3,400$. When their cognitive flexibility was examined, it was found that alternatives sub-dimension was $48.333 \pm 7.098$ control sub-dimension was $27.589 \pm 3.553$ and the total cognitive flexibility levels were $75.922 \pm 10.407$.

Table 4 Relationship Between Academic Self-Efficacy and Cognitive Flexibility Levels of Participants

\begin{tabular}{llllll}
\hline & Alternatives & Control & $\begin{array}{l}\text { Cognitive } \\
\text { Total }\end{array}$ & Flexibility \\
\hline Academic Self-Efficacy & $\mathrm{r}$ & .391 & .395 & .401 \\
& $\mathrm{p}$ & .000 & .000 & .000 & \\
\hline
\end{tabular}


When Table 4 was examined, A moderate positive correlation was found between the academic self-efficacy and cognitive flexibility alternatives $(\mathrm{r}=.391, \mathrm{p}=.000)$ and control $(\mathrm{r}=.395, \mathrm{p}=.000)$ sub-dimensions and cognitive flexibility totals $(\mathrm{r}=.401, \mathrm{p}=.000)$ of physical education and sports teacher candidates.

\section{Discussions and Conclusion}

In order to become an information society, each individual need to have strong self-efficacy, be researcher, and improve him/her continuously. In order to provide these competencies to individuals, first of all, the educators who will train them must have these characteristics. It is thought that the academic self-efficacy of the educators who will set an example for the individuals should be strong in order to develop themselves academically.

In this study, it was determined that the self-efficacy, cognitive flexibility total scores and subdimensions of the physical education and question teacher candidates were above the average (Table 3).

Bandura (1994) stated that many factors affect self-efficacy. First of all, he stated that the first factors affected are individuals' conceptual or analytical thinking abilities. It was stated that individuals with high self-efficacy beliefs also have high cognitive flexibility. (Martin and Rubin, 1995). Individuals who state that they are cognitively flexible are also stated to be very selfconfident and see themselves as ready-made, careful, and understanding (Martin and Anderson 1996; Martin and Anderson 1998). In this study, it can be thought that the reason why the academic self-efficacy and cognitive flexibility levels of physical education and sports teacher candidates are above average is because of the feature that the sports branches they are engaged in provides them.

A moderate positive correlation was found between the alternatives, control sub-dimensions and cognitive flexibility total of the academic self-efficacy and cognitive flexibility of physical education and sports teacher candidates (Table 4).

In the literature review made by the researcher, it was observed that there are studies supporting that self-efficacy is associated with academic motivation (Alemdağ et al, 2014) academic success (Koca and Dadand1, 2019), performance approach orientation (Bell and Kozlowski, 2002) academic achievement goal orientation (Aydin 2014) and athlete identity perception (Caba and Pekel, 2017). Similarly, the studies reporting the relationship between cognitive flexibility, sense of humor (Kolburan et al, 2019), attitude towards social media use (Peker and Çukadar, 2016), social problem solving style (Buğa et al, 2018), stress (Turan et al, 2019), academic, emotional and social competence (Çelikkaleli, 2014) and personality characteristics (Bilgin 201) were encountered.

Academic self-efficacy is defined as the perception that an individual can do an academic task at the level of determined success (Ekinci, 2011). Within the scope of self-efficacy, in order to demonstrate and produce a skill or success in performing a given task, the individual has beliefs about the abilities and skills in organizing and achieving or performing the way of behaviour or actions required (Totan et al, 2010). It has been stated that those with high self-efficacy will choose more difficult goals, maintain their analytical thinking skills, and complete the assigned tasks on time and successfully (Aşkar and Umay, 2001). The individual's self-efficacy or ability to be flexible, as well as awareness of alternative ways and options, willingness to be flexible and adapt to situations are expressed as three basic elements of cognitive flexibility (Martin and Anderson, 1998). Individuals with cognitive flexibility are aware of options, can effectively deal with new and difficult situations, produce alternative thoughts and ideas, and are competent in adapting to new situations (Bilgin, 2009; Stahl and Pry, 2005). They consider themselves competent in interpersonal relationships, are assertive and responsible, shows interest and can make sense of their experiences. (Martin and Anderson 1996; Martin and Anderson 1998). In this study, it is thought that the positive relationship between the academic self-efficacy and cognitive flexibility of the physical education and sports teacher candidates is result of the fact that the participants can successfully transfer their experiences in their sports life to the theoretical and 
applied courses within the scope of the program they study, and they have proficiency about generating alternative thinking, new ideas and adapting to new situations thanks to their experiences that they have gain in their sports life in solving the problems they encounter in this process.

As a result, it was determined that the academic self-efficacy and cognitive flexibility levels of physical education and sports teacher candidates were above average. A moderate positive relationship was found between academic self-efficacy and cognitive flexibility with alternatives, control sub-dimensions and cognitive flexibility total. It is thought that this is due to the fact that the physical education and sports teacher candidates can transfer their experiences that they gain in their sports life into their education life.

\section{Suggestions}

- Studies on larger scale involving physical education and sports teacher candidates can be conducted.

- Studies involving coaching education, sports management and recreation specialization students who are educated in Sport Sciences can be carried out.

- Studies involving physical education and sports teachers working under the Ministry of National Education can be conducted.

- Studies involving Trainers, Sports Managers and Recreation experts working under the Ministry of Sports can be conducted.

\section{References}

Akıncı, A.Y. (2020). The Relationship between Teacher Candidates' Self-Efficacy and Attitudes of Sports History. International Education Studies, 13(7), 105-112.

Alemdağ, C., Öncü, E., \& Yılmaz, A. (2014). Beden Eğitimi Öğretmeni Adaylarının Akademik Motivasyon ve Akademik ÖzYeterlikleri. Hacettepe Spor Bilimleri Dergisi, 25(1), 23-35.

Alper, A. \& Deryakulu, D. (2008). Web Ortamlı Probleme Dayalı Öğrenmede Bilişsel Esneklik Düzeyinin Öğrenci Başarısı ve Tutumları Üzerindeki Etkisi. Eğitim ve Bilim; 33 (148), 4963.

Aslan Ş. (2018). Examination of Cognitive Flexibility Levels of Young Individual and Team Sport Athletes. Journal of Educationand Training Studies; 6 (8): 149-154.

Aşkar. P. \& Umay. A. (2001). İlköğretim Matematik Öğretmenliği Öğrencilerinin Bilgisayarla İlgili Öz-yeterlik Algısı. Hacettepe Üniversitesi Eğitim Fakültesi Dergisi; 21. 1-8.

Aydın, S. (2014). Investigation of the Relationship between Preservice Science Teachers' Achievement Goal Orientations and Academic Self-Efficacy with Structural Equation Model. Turkish Studies-International Periodical for the Languages, Literature and History of Turkish or Turkic, 9(2), 221-230.

Bandura, A. (1997). Self-efficacy: The exercise of control. New York: W.H. Freeman and Company. Pp:3

Bandura. A. (1994) Self-Efficacy. In V.S. Ramachaudran Encyclopedia of Human Behavior. Academic Press. New York; 4. 71-81.

Bell, B.S., \& Kozlowski, W.J. (2002). Goal Orientation and Ability: Interactive Effects on SelfEfficacy, Performance, and Knowledge. Journal of Applied Psychology, 87, 497-505.

Bilgin, M. (2017). Ergenlerin Beş Faktör Kişilik Özelliği ile Bilişsel Esneklik İlişkisi. Elektronik Sosyal Bilimler Dergisi, 16 (62), 945-954.

Bilgin. M. (2009). Bilişsel esnekliği yordayan bazı değişkenler. Çukurova Üniversitesi Eğitim Fakültesi Dergisi, 36(3), 142-157.

Buğa, A., Özkamalı, E., Altunkol, F., \& Çekiç, A. (2018). Üniversite öğrencilerinin bilişsel esneklik düzeylerine göre sosyal problem çözme tarzlarının incelenmesi. Gaziantep Üniversitesi Eğitim Bilimleri Dergisi, 2(1), 48-58.

Büyüköztürk Ş. (2007). Sosyal Bilimler İçin Veri Analizi El Kitabı, (7.baskı), Ankara, Pegem Akademi Yayıncılık; 40 
Caba, U., \& Pekel, A. (2017). Relationship between General Self-Efficacy Levels and Athlete Identity Perceptions of University Students (An Example of Foundation University). The Journal of Academic Social Science, 5(55), 475-482.

Canas, J.J., Quesada, J.F.,Antoli, A., Fajardo, I. (2003). Cognitive Flexibility and Adaptability to Environmental Changes in Dynamic Complex Problem-Solving Tasks. Ergonomics, Vol. 46, No 5, $482-501$

Çelikkaleli, Ö. (2014). Ergenlerde bilişsel esneklik ile akademik, sosyal ve duygusal yetkinlik inançları arasındaki ilișki. Eğitim ve Bilim, 39(176). 347-354.

Dalbudak, I., \& Musa, M. (2019). Analysis of Self Efficacy-Sufficiency Levels of Individuals with Visual Impairment According to Some Variables. International Education Studies, 12(10), 75-88.

Dalkı1ıç M. (2017). The Effect of Cognitive Flexibility of Athletes on Person-Organization. International Journal of Science Culture and Sport; 5 (3): 213-224

Deak, G.O. (2003). The Development of Cognitive Flexibility and Language Abilities. Advances in Child Development and Behavior; 31, 271-327.

Dennis, J.P. \& Vander Wal, J.S. (2010). The Cognitive Flexibility İnventory: Instrument Development and Estimates of Reliability and Validity. Cognitive Therapy and Research; 34, 241-253.

Diril, A. (2011). Lise öğrencilerinin bilişsel esneklik düzeylerinin sosyo-demografik değişkenler ve öfke düzeyi ile öfke ifade tarzları arasındaki ilişki açısından incelenmesi. Yüksek lisans tezi, Çukurova Üniversitesi, Sosyal Bilimler Enstitüsü, Adana.

Donmuş, V., Akpınar, V., \& Eroğlu, M. (2017). Öğretmen Adaylarının Akademik Öz yeterlikleri ve Mesleki Kaygıları Arasındaki İlişkinin İncelenmesi. Mustafa Kemal Üniversitesi Sosyal Bilimler Enstituisü Dergisi, 14(37), 1-13.

Dreisbach, G., \& Goschke, T. (2004). How Positive Affect Modulates Cognitive Control: Reduced Perseveration at The Cost of İncreased Distractibility. Journal of Experimental Psychology: Learning, Memory, and Cognition; 30 (2), 343-353.

Ekinci. E. (2011). Ortaöğretim Öğrencilerinin Akademik Öz-yeterlik Düzeyleri ve Akademik Erteleme Davranışlarının Öğrenilmiş Çaresizlik Düzeylerini Yordama Gücü. Yayımlanmamış Yüksek Lisans Tezi. Gaziosmanpaşa Üniversitesi Sosyal Bilimler Enstitüsü. Tokat.

Erdoğan, S.C. (2018). Üstün Zekalilar Öğretmenliği Adaylarinin Bilişsel Esneklik Düzeylerinin İncelenmesi. Celal Bayar Üniversitesi Sosyal Bilimler Dergisi, 16(03), 77-96.

George D, Mallery P. (2016). IBM SPSS Statistics 23 Step by Step: A Simple Guide and Reference. NewYork: Routledge; 112-120

Hamtiaux, A. ve Houssemand, C. (2012). Adaptability, cognitive flexibility, personal need for structure, and rigidity. Psychology Research, 2(109), 563-585.

Jerusalem, M., \& Schwarzer, R. (1981). Fragebogen zur Erfassung von' Selbstwirksamkeit. Skalen zur Befindlichkeit und Persönlichkeit in R Schwarzer (Hrsg.). (Forschungsbericht No.5). Berlin: Freie Universitaet, Institut fuer Psychologie.

Karasar, N. (2004). Bilimsel araştırma yöntemi. Nobel yayıncılık, Ankara, 52.

Kim, B. S. K. ve Omizo, M. M. (2005). Asian and European American cultural values, collective self-esteem, acculturative stress, cognitive flexibility, and general self-efficacy among Asian American college students. Journal of Counseling Psychology, 52(3), 412-419.

Koca F., \& Dadandı İ. (2019). Akademik Öz-Yeterlik ile Akademik Başarı Arasındaki İlişkide Sınav Kaygısı ve Akademik Motivasyonun Aracı Rolü. İlköğretim Online, 18(1), 241-252.

Kolburan, Ș. G., Eker, E., \& Akdeniz, B. (2019). Bilișsel Esneklik ve Mizah Stilleri Arasındaki İlişkinin Değerlendirilmesi. Türkiye Klinikleri Adli Tıp ve Adli Bilimler Dergisi, 16(1), 113.

Martin, M.M. ve Anderson, C.M. (1996). Communication traits: A cross-generational investigation. Communication Research Reports, 13, 58-67.

Martin, M.M. ve Anderson, C.M. (1998). The Cognitive Flexibility Scale: Three validity studies. Communication Repots, 11, 1-9.

Martin, M.M. ve Rubin, R.B. (1995). A new measure of cognitive flexibility. Psychological Reports, 76, 623-626. 
Pajares, F. (1996). Self-efficacy beliefs in academic settings. Review of Educational Research, 66(4), 543-578.

Peker, A., \& Çukadar, F. (2016). Bilişsel esneklik ile sosyal medyayı kullanmaya yönelik tutum arasındaki ilişkinin incelenmesi. Sakarya University Journal of Education, 6(2), 66-79.

Sapmaz F, Doğan T. (2013). Bilişsel Esnekliği Değerlendirilmesi: Bilişsel Esneklik Envanteri Türkçe Versiyonunun Geçerlik ve Güvenirlik Çalışmaları. Ankara Üniversitesi Eğitim Bilimleri Fakültesi Dergisi; 46 (1): 143-161.

Saracaloğlu, A. S., Aldan, K. Ç., Dursun, F., Altın, M., \& Üstündağ, N. (2017). The Relationship between Self-Regulation Learning Skills, Academic Self-Efficacy, Focus of Academic Control and Academic Achievement of Prospective Primary School Teachers. Turkish Studies International Periodical for the Languages, Literature and History of Turkish or Turkic, 12(33), 379-402.

Stahl, L., \& Pry, R. (2005). Attentional flexibility and perseveration: Developmental aspects in young children. Child Neuropsychology, 11(2), 175-189.

Totan. T. İkiz. E. ve Karaca. R. (2010). Duygusal Öz-yeterlik Ölçeğinin Türkçe 'ye Uyarlanarak Tek ve Dört Faktörlü Yapısının Psikometrik Özelliklerinin İncelenmesi.Dokuz Eylül Üniversitesi. Buca Egitim Fakültesi Dergisi; 28. 71- 95.

Turan, M. B., Karaoğlu, B., Kaynak, K., \& Osman, P. (2016). Özel Yetenek Sinavlarına Giren Adayların Genel Öz Yeterlilik Düzeylerinin Bazı Değişkenlere Göre İncelenmesi. Spor Bilimleri Araştırmaları Dergisi, 1(1), 17-26.

Turan, N., Durgun, H., Kaya, H., Ertaş, G., \& Kuvan, D. (2019). Hemşirelik öğrencilerinin stres durumları ile bilişsel esneklik düzeyleri arasındaki ilişki. Jaren, 5(1), 59-66.

Yılmaz, M., Gürçay, D., \& Ekici, G. (2007). Adaptation of the Academic Self-Efficacy Scale to Turkish. Hacettepe University. Journal of Education, 3, 253-259.

Yılmaz, T., Yiğit, Ş., Dalbudak, İ., \& Acar, E. (2020). Investigation of University Students' SelfEfficacy and Sport Specific Success Motivation Levels. Electronic Turkish Studies, 15(3). 